\title{
Does the Perception of Organizational Cronyism Leads to Career Satisfaction or Frustration with Work? The Mitigating Role of Organizational Commitment
}

\author{
Aygül Turan ${ }^{1, *}$ \\ ${ }^{1}$ Economics and Administrative Programs, Yildiz Technical University, Istanbul, Turkey \\ *Correspondence: Economics and Administrative Programs, Yildiz Technical University, \\ Istanbul, Turkey. E-mail: ayturan@yildiz.edu.tr
}

Received: August 15, 2015 Accepted: August 30, 2015 Published: September 27, 2015

doi:10.5296/rae.v7i3.8164 URL: http://dx.doi.org/10.5296/rae.v7i3.8164

\begin{abstract}
The concept of organizational cronyism has been investigated to explain different concepts in the literature. In this study, we aim at researching the influence of organizational cronyism on organizational commitment of individuals and explain how the influence differentiates their career satisfaction or frustration with work perception of individuals. Therefore, we focused on government officials working in a public institution and examine their perception of cronyism in the organization. Having gathered the data from 193 government officials, confirmatory as well as explanatory factor analyses initially was initially conducted on the scales of organizational cronyism, organizational commitment, career satisfaction and frustration with work. After controlling the validity and reliability of the scales, measurement model and structural model testing were carried out. Results indicated that organizational commitment partially mediated the relationship between organizational cronyism and career satisfaction. In addition, organizational commitment partially mediated the relationship between organizational cronyism and frustration with work.
\end{abstract}

Keywords: Cronyism, Favoritism, Organizational Commitment, Frustration with Work, Career Satisfaction, Confirmatory Factor Analysis, Measurement Model, Structural Equation Modeling. 


\section{Introduction}

In public organizations, it is possible to experience exploitation in terms of organizational politics instruments, especially recruiting or promoting individuals who support their superiors (Martins, 2010; Rauh, 2015; Ozsemerci, 2003). Many examples could be given in private or public companies to explain how individuals favor someone or some groups of employees over others to dominate interpersonal relation rather than objective criteria, such as Enron, WorldCom (Khatri and Tsang, 2003). It is at this point that organizational cronyism manifests itself to be an important concept to shed light on the effects of organizational exploitation on the outcomes of the organization by using the means of organizational political tools.

In the present research, we argue theoretically and investigate empirically that organizational cronyism influences employees' career satisfaction and frustration with work. In order to increase their career satisfaction and decrease their frustration with work, the proposed model of the research asserts that employees should not perceive organizational cronyism and employees are highly committed to their organization. On the basis of the literature on favoritism in public organizations, this research was conducted on government officials in a public organization. The implication of research is interpreted from that framework.

\section{Theoretical Framework and Hypotheses Development}

\subsection{Organizational Cronyism}

Showing favor to somebody among the members of in-group is a phenomenon discussed and investigated over the years. In-group members could come from a family, organization, political party, ethnic origin etc. The concept of favoritism explains that individuals favor somebody over others in a group. Favoritism has a number of different names depending on the context it is exercised: nepotism, cronyism, political favoritism (patronage) (Turhan, 2014). The concept of nepotism has derived from the term of "nepot" in Latin or "nephew" in English and it means individuals favor someone from their family or relative over others (Abdalla et al., 1998: 555). The concept especially was explained in the literature to mention recruiting or promoting individuals to a position according to their affinity rather than their ability or performance (Asunakutlu and Avci, 2010; Turhan, 2014). A growing body of literature about nepotism is comprised of family firm investigations (Asunakutlu and Avci, 2010; Keles et. al., 2011; Salvato et al., 2012). Some of the researches evaluate the concept and speak favorably of it (to facilitate firm sustainability, contribution to success of firm, harmony of family members etc.) (Abdalla et al., 1998; Bellow, 2003; Garih, 2000); on the contrary, others approach the concept from a negative perspective (devoid of organizational justice, job satisfaction etc.) (Arasli and Tumer, 2008).

Cronyism is a broad concept in comparison with nepotism in terms of its scope; favoritism is shown towards not only family or relative members but also acquaintances, friends, citizens, individuals with similar points of view. Therefore, cronyism has been investigated to a large extent within social, legal, political and organizational framework (Turhan, 2014). Samples of 
the researches about cronyism have been differentiated from employees in organizations to teachers in school/ universities, political party members, ethnic group members etc (Turner et al., 1979; Meric and Erdem, 2013; Chang et al., 2014; Arasli and Tumer, 2008; Hong, 2015).

The concept of organizational cronyism was identified as "any privileged favored treatment by the manager towards certain employees based on factors (personal relationships, personal loyalty etc.) not being related to performance criteria or formal procedures from the perspective of employees" (Turhan, 2014). In addition, organizational cronyism is shown to offer not only reward, promotion, recruitment process of employees but also good working conditions, enabling to participate in decision making, giving permission easily to employees by managers (Blase and Blase 2003; 2006).

Khatri and Tsang (2003) define the concept of organizational cronyism as "unfair use of organizational power and authority" and categorize the concept into two different subcategories: horizontal and vertical cronyism. Horizontal cronyism is defined as favor shown by employees at a higher hierarchical level more than to those at the same level (colleagues, friends etc). On the other hand, vertical cronyism was identified as managers' favoring some of the employees over others.

\subsection{Organizational Commitment}

Organizational commitment is a key construct to investigate employees' suitability for an organization (Marsden et. al, 1993) and psychological attachment to the organization (Chatman and O'Reilly, 1990). Individuals are highly committed to their organization which they work for, eager to make extra effort for the organization and identify themselves with the organization (Steers, 1977). So all managers are willing to work with committed employees presumed to have higher level performance and lower level turnover and absenteeism (Mowday et al., 1982).

One of the studies conducted in China indicates that commitment to organization could arise from commitment to superiors (Chen and Francesco, 2000). For employees' tasks, performance evaluations or rewards were organized by their superiors. That situation leads to particularism and as a result employees incline to develop attachment to superiors rather than the organization itself. Such an outcome increases cronyism and helps it spread within the organization (Khatri and Tsang, 2003). Furthermore, Pearce et al. (2000) claims that particularism affects organizational commitment in a negative way. "Owing to in-group bias the efforts of outgroup members are often unrecognized by their superior" (Khatri and Tsang, 2003). Then, out-group members perceive that in-group members are favored over them by their superior. Therefore, out-group members show low commitment to organization (Khatri and Tsang, 2003). Supporting this claim, Bute (2011) has found nepotism has significant negative effects on organizational commitment and human resource management practices. Following the previous implication, we propose the following hypothesis:

Hypothesis 1: There is a negative relationship between organizational cronyism and organizational commitment. 


\subsection{Career Satisfaction}

The concept of career was proposed by Anne Roe in her book of 'Psychology of Duties' (1956). Immediately after that, researches about career have been rapidly grown in the human resource management literature. According to Schein (1975) career is a set of occupational experiences and roles which constitute working life of individuals. Beyond the concept of career, career satisfaction refers to individuals' perception of their career progression. Career satisfaction was explained on the basis of career choice theory by Holland (1959) and Super (1980) as well as dual factor theory of Herzberg (1964). Career satisfaction was defined as satisfaction that individuals derive from the intrinsic and extrinsic aspects of their careers, including pay, advancement, and developmental opportunities (Greenhaus et al., 1990). Career satisfaction is also identified as the level of overall happiness experienced through one's choice of occupations.

According to Dobson et al., (2007) and Mc Ginley (2009), work conditions, allocation rewards and workload, stress and conflict among the employees determine the career satisfaction. There could be found some researches indicating career satisfaction and organizational justice. One of the researches points out that organizational justice is a positive antecedent of career satisfaction (Oh, 2014). Tremblay et al. (2014) claims that employees' perception of organizational justice is damaged by perception of favoritism. Another research indicates organizational justice and career plateau is negatively in relation to each other (Park, 2011). Confirming the assertion, improving working conditions and designing career improvement programs without favoritism cause organizational commitment and satisfaction with organization (Ferrinho et al., 2004; Zinnen et al., 2012). In addition, employees' commitment to organization is vital for their career prospects. Highly committed employees might have better career prospects (Marsden et al., 1993). Nevertheless, high commitment has negative effects on individuals' stress and career stagnation (Mathieu and Zajac, 1990; Mowday et al., 1982). On the basis of the previous researches' results, we propose the following hypotheses:

Hypothesis 2: There is a negative relationship between organizational cronyism and career satisfaction.

Hypothesis 3: There is a positive relationship between organizational commitment and career satisfaction.

\subsection{Frustration with Work}

Frustration is a response which emerges as defensing individuals' ego to interference in goal achievement (Rosenzweig, 1944). Furthermore, perceived frustration is an emotional reaction to frustrating facts (Storms and Spector, 1987) and it could cause negative emotional consequences composed of disinclination and suppression (Spector, 1978).

Many researches claim that the concept of frustration leads to supporting perceived politics (Rauh, 2015; Rosen et al., 2009), harming justice (Lillis et al., 2007), instigating employees to exhibit counterproductive behavior (Fox and Spector, 1999). "Supervisor ego-nurturing behavior, when persistent and focused, provokes frustration because it introduces bias that 
affects subsequent interactions and reward decisions" (Hochwarter and Thompson, 2012:341). In addition, if a supervisor refuses and eradicates the opportunity of employees' development, frustration with organization could increase (Aasland et al., 2010). One of the researches investigating frustration of nurses indicates that organizational commitment and work excitement are positively interrelated; on the contrary, organizational commitment and frustration are negatively in relation with each other (Chang et al., 2014). Taking previous researches into consideration, we propose the following hypotheses:

Hypothesis 4: There is a negative relationship between organizational commitment and frustration with organization.

Hypothesis 5: There is a positive relationship between organizational cronyism and frustration with organization.

On the basis of the literature review and hypotheses, the research model of the study is illustrated in Figure 1.

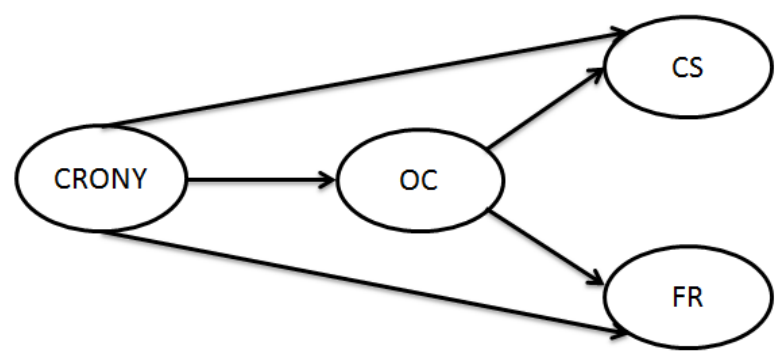

Figure 1. The Proposed Model

$\mathrm{CRONY}=$ organizational cronyism, $\mathrm{OC}=$ organizational commitment, $\mathrm{CS}=$ career satisfaction, $\mathrm{FR}=$ frustration with work

\section{Method}

\subsection{Sample}

A growing body of researches investigating favoritism has been conducted on family members in family firms (Salvato et al., 2012; Asunakutlu and Avci, 2010; Keles et. al., 2011), teachers and students at schools (Turner et al., 1979; Meric and Erdem, 2013; Turhan, 2014), nurses in hospitals (Chang et al., 2014), employees in banks (Arasli and Tumer, 2008), taste-neutral firms (Goldberg, 1982) senior public servants (Brewer et al., 2015) and police representatives (Hong, 2015) in public organization as well as HRM professionals in various firms (Abdalla et al., 1998).

Nepotism, favoritism and cronyism are also important concepts in public institutions to investigate. Therefore, government officials working in a public institution in Turkey are within the scope of the present research. The questionnaire was sent to all government officials in such institutions (totally 713 individuals) via e-mail. We obtained 193 valid questionnaires from them. The response rate is $27 \%$. Sample characteristics indicated that among 193 respondents, $62 \%$ are male, $45 \%$ are between the ages of 26 and 35; 37\% are 
university graduates, $26 \%$ have more than five years of work experience and all of them have Turkish nationality.

\subsection{Measures}

The measurement instrument of present study consists of 27 five-point likert type items anchored by $1=$ strongly disagree and $5=$ strongly agree - that were measured by the concept of organizational cronyism, organizational commitment, career satisfaction, frustration with work. In addition, it has four open ended questions to get demographic characteristics of individuals (age, education level, tenure and gender).

\subsubsection{Organizational Cronyism}

The concept of organizational cronyism was measured using Abdalla et al.'s (1998) 'arguments against nepotism scale' with 10 items and its reliability was relatively good $(\mathrm{r}=.80)$. Subsequent researches confirmed Abdalla et al.'s (1998) result that items are loaded in a factor with .70 internal consistency (Arasli and Tumer, 2008). On the other hand, Asunakutlu and Avci (2010) adopted Abdalla et al.'s (1998) scale and items loaded three factors with 86 Crombach Alpha value.

We conducted explanatory factor analysis for cronyism scale and obtained three factors similar to Asunakutlu and Avci's (2010) implications. One item had to be dropped because of violation factor structure of the concept. Three factors were titled 'cronyism in reward and promotion', 'cronyism in recruitment' and 'in-group bias' as in the previous researches (Asunakutlu and Avci, 2010; Turhan, 2014). As a consequence, present research indicates that cronyism scale explained 67,831 percent of variances with 0,826 Crombach alpha value.

Contributing to previous researches, we conducted confirmatory factor analysis for organizational cronyism scale used in the literature (Asunakutlu and Avci, 2010). Results of confirmatory factor analysis indicated following goodness of fit scores $X 2 / d f(2.23, N=193)$; $p<.05 ; \mathrm{RMESA}=.086$; GFI $=.93 ; \mathrm{RMR}=.069 ; \mathrm{CFI}=.94 ; \mathrm{IFI}=.94(90 \%$ confidence interval for RMSEA $=.062 ; .11)$. As mentioned before, since one of the items from in-group bias factor violated the factor structure, we dropped it and conducted confirmatory factor analysis with the remaining items. As a result, we obtained better goodness of fit scores than previous one as $X 2 / d f(1.22, N=193) ; p>.05$; RMESA $=.034$; GFI $=.97$; RMR $=.047$; CFI $=.99$; IFI $=.99(90 \%$ confidence interval for RMSEA $=.00-.07)$. All of the factor loadings were statistically significant, and standardized values ranged from .91 to .36 . The second measurement instrument is better in comparison with the first one according to goodness of fit scores; therefore, we have used it to define organizational cronyism scale in measurement and structural model in the following section. The final factors could be seen in the diagram illustrated in Appendix 1.

\subsubsection{Organizational Commitment}

A growing body of literature about organizational commitment indicates that different organizational commitment scales were applied in researches. Meyer and Allen's (1997) affective, normative, continuance commitment scale and Mowday et. al's (1982) global 
organizational commitment scale are among the most commonly preferred ones. In the present research, organizational commitment was measured by Marsden et al.'s (1993) overall organizational commitment scale with six items which were derived by Lincoln and Kalleberg's (1990) American-Japanese work commitment study (Fields, 2002). Marsden et al. (1993) also indicated that scale coefficient alpha was .78. In order to control the reliability and validity of the scale, we conducted explanatory factor analysis and found unidimensional factor structure. In addition, organizational commitment explained 55,130 percent of variances with .83 Cronbach alpha value.

\subsubsection{Career Satisfaction}

Career satisfaction scale developed by Greenhaus et al. (1990) measures career success and defines career outcome. In addition to general satisfaction with career progress, it measures satisfaction with income level, advancements and development of skills (Fields, 2002). However, career satisfaction scale is distinct from financial success and hierarchical success in an organization (Aryee et al., 1994). Career satisfaction coefficient alpha ranged from .83 to .89 according to Greenhaus et al's (1990) and their following researches' study (Aryee et al., 1994; Seibert et al., 1999). We applied Greenhaus et al.'s (1990) five-item-career satisfaction scale and done explanatory factor analysis in the present study. Results indicate that career satisfaction items loaded in a factor with .89 Cronbach's alpha internal consistency coefficient and 70.964 percent of variances was explained.

\subsubsection{Frustration with Work}

Frustration with work scale consisting of three items was developed by Peters et al., (1980) and defined whether or not employees perceive their job as frustrating. Coefficient alpha values of previous researches vary from .67 to .84 (Fortunato et al., 1999; Jex and Elacqua, 1999; Jex et al., 1992; Jex and Gudanowski, 1992; Spector and O'Connel, 1994). In the present research, we used Peters et al., (1980) frustration with work scale and then explanatory factor analysis was conducted on it. The Cronbach's alpha internal consistency coefficient for the present data showed relatively low reliability as .46 and frustration with work scale explained 48.040 percent of variances.

\subsection{Results}

\subsubsection{Descriptive Statistics}

Means, standard deviations and zero-order correlations among 13 observed variables are shown in Table 1. Mean scores indicate that individuals' cronyism perception, organizational commitment are above the mean score (3); however, frustration and career satisfaction are about or below the mean score. In addition, kurtosis values of observed variables differentiates from -1.045 to .489 and skewness from -.962 to .610. On the basis of the results, we could interpret there is no problem for normality assumption. 
Table 1. Means, Standard Deviations and Correlations among Observed Variables used in the Research Model

\begin{tabular}{|c|c|c|c|c|c|c|c|c|c|c|c|c|}
\hline Variable & $\mathrm{M}$ & SD & PRO & REC & BIAS & OCP1 & OCP2 & CSP1 & CSP2 & $\mathrm{F} 1$ & $\mathrm{~F} 2$ & F3 \\
\hline PRO & 3.71 & 1.02 & 1 & & & & & & & & & \\
\hline REC & 3.57 & .909 & $.374^{* *}$ & 1 & & & & & & & & \\
\hline BIAS & 3.17 & .894 & $.489^{* *}$ & $.416^{* *}$ & 1 & & & & & & & \\
\hline OCP1 & 3.10 & 1.02 & $-.479^{* *}$ & -.092 & $-.246^{* *}$ & 1 & & & & & & \\
\hline OCP2 & 3.66 & .972 & $-.235^{* *}$ & .057 & -.137 & $.649^{* *}$ & 1 & & & & & \\
\hline CSP1 & 3.00 & .969 & $-.459^{* *}$ & -.004 & -.136 & $.421^{* *}$ & $.343^{* *}$ & 1 & & & & \\
\hline CSP2 & 3.05 & 1.12 & $-.402^{* *}$ & -.062 & $-.159^{*}$ & $.327^{* *}$ & $.241^{* *}$ & $.822^{* *}$ & 1 & & & \\
\hline $\mathrm{F} 1$ & 2.58 & 1.14 & $.317^{* *}$ & $.145^{*}$ & $.233^{* *}$ & $-.300^{* *}$ & $-.149^{*}$ & $-.221^{* *}$ & $-.243^{* *}$ & 1 & & \\
\hline $\mathrm{F} 2$ & 3.11 & 1.19 & $.446^{* *}$ & $.142^{*}$ & $.273^{* *}$ & $-.381^{* *}$ & $-.320^{* *}$ & $-.286^{* *}$ & $-.289^{* *}$ & $.337^{* *}$ & 1 & \\
\hline F3 & 2.70 & .981 & .112 & .005 & -.038 & -.119 & -.133 & -.097 & $-.146^{*}$ & .124 & $.178^{*}$ & 1 \\
\hline
\end{tabular}

$\mathrm{N}=193$; The first three constructs are factors of organizational cronyism (CRO) construct where PRO $=$ cronyism in reward and promotion, $\mathrm{REC}=$ cronyism in recruitment, BIAS $=$ in-group bias. OCP1-OCP2 = two parcels of organizational commitment (higher scores show higher level of perception about organizational commitment); CSP1-CSP2 = two parcels of career satisfaction (higher scores show higher level of perception about career satisfaction). F1-F2-F3 items of frustration with organization (higher scores indicates higher levels of frustration with organization).

$* p<.05 ; * * p<.01$

\subsubsection{Test of the Measurement Model}

All possible associations among observed variables were examined with measurement model that enables variables to inter-correlate freely (Simsek and Kuzucu 2012). In addition, Anderson and Gerbing (1988) claim that measurement model should be evaluated before structural model testing. In this study, structural model consists of four latent variables as CRO (cronyism), OC (organizational commitment), CS (career satisfaction) and FR (frustration with work). Construct of CRO consisted of three factors as PRO (cronyism in reward and promotion), REC (cronyism in recruitment) and BIAS (in-group bias). Furthermore, the OC latent variable was defined using the two parcels. CS latent variable was defined as two parcels, as well. The items of frustration with work were used to be indicators of FR latent construct, because the frustration scale had three items.

The initial test of the measurement model results indicated good fit to data $X 2 / d f(1.77, N=$ $193) ; \mathrm{p}<.05 ; \mathrm{RMESA}=.064 ; \mathrm{RMR}=.051 ; \mathrm{CFI}=.96$; IFI $=.96$; GFI $=.95(90 \%$ Confidence Interval for RMSEA $=.034-.091)$. The parameter estimates of the measurement model are depicted in Figure 2. The $t$ values of the factor loadings range from 2.83 to 14.01, indicating that all of them load significantly in their relevant constructs. The correlation coefficients among the constructs are higher than zero-order correlation in Table 2, so it is possible to say that errors are eliminated by constructing the latent variable. 


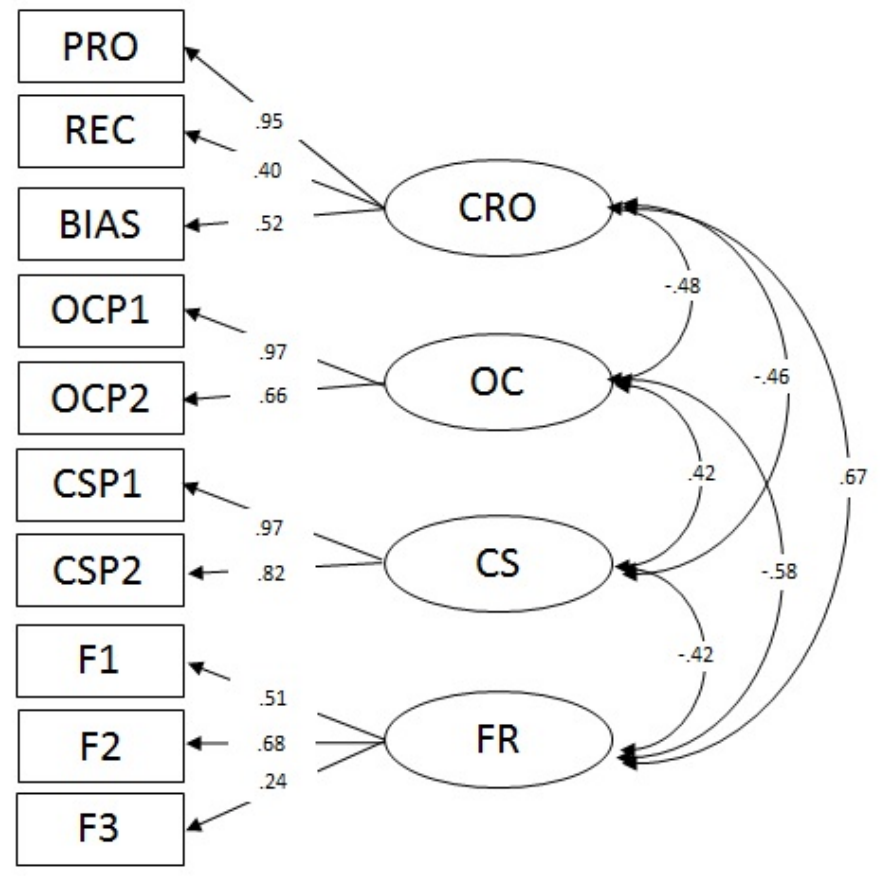

Figure 2. Standardized solution estimates of the measurement model.

$\mathrm{N}=193$; CRO organizational cronyism; OC organizational commitment; CS career satisfaction; FR frustration; First three observed variable are the factors of organizational cronyism $(\mathrm{CRO}) ; \mathrm{PRO}=$ cronyism in reward and promotion, $\mathrm{REC}=$ cronyism in recruitment, BIAS = in-group bias. OCP1-OCP2 = two parcels of organizational commitment; CSP1-CSP2 = two parcels of career satisfaction; F1-F2-F3 items of frustration with organization. All parameters are significant at the $p<.01$.

As seen in Figure 2, correlation coefficients among all latent constructs are statistically significant. First, organizational cronyism is negatively correlated with organizational commitment (-.48) and career satisfaction (-.46). Organizational commitment and career satisfaction are also positively in relation (.42). Second, there was a positive relationship between organizational cronyism and frustration with work (.67) as well as negative relationship between organizational cronyism and organizational commitment (.48). In addition, organizational commitment and frustration with work are negatively in relation (-.58). Finally, these significant relations indicated that Baron and Kenny's (1986) methodology should be used to test mediations of the structural model.

\subsubsection{Test of the Structural Model}

Proposed model (Figure 1) in the present research was analyzed and helped to obtain good fit of data: $X 2 / d f(1.73, N=193) ; p<.05 ; \mathrm{RMESA}=.062 ; \mathrm{RMR}=.054 ; \mathrm{CFI}=.96$; IFI = .97; GFI $=.95(90 \%$ Confidence Interval for RMSEA $=.032-.089)$. In order to get the best fit to the data, we used the nested model strategy developed by Anderson and Gerbing (1988) for the mediation analyses. Two direct paths from CRO to CS and from CRO to FR were omitted one by one and then were evaluated to check the structural model goodness of fit scores. First we omitted the path from CRO to CS from the structural model and obtained the following 
goodness of fit scores: $X 2 / d f(2.00, \mathrm{~N}=193) ; p<.05$; RMESA $=.072$; RMR $=.074$; CFI $=.94 ; \mathrm{IFI}=.94 ; \mathrm{GFI}=.94(90 \%$ Confidence Interval for RMSEA $=.046-.098)$. The Chi-Square difference test $(62.01-51.97=10.04 ; d f=1 ; p<.05)$ indicated that deleting the path worsened the model goodness of fit of the data. Thus, this path should not be omitted from the model. So we accepted first, second and the third hypotheses.

Second, by deleting the path from CRO to FR, the model produced the following goodness of fit statistics: $X 2 / d f(2.36, N=193) ; p<.05 ; \mathrm{RMESA}=.084 ; \mathrm{RMR}=.080 ; \mathrm{CFI}=.93 ; \mathrm{IFI}=.93$; $\mathrm{GFI}=.93(90 \%$ Confidence Interval for RMSEA $=.060-.11)$. According to the nested model strategy (Anderson and Gerbing 1988), deleting this path produced worse goodness of fit scores than the proposed model (Chi-Square difference $73.43-51.97=21.46 d f=1 ; p<.05$ ). Taking the results into consideration, we could not omit this path from the model. As a result, hypothesis 4 and hypothesis 5 were accepted.

On the basis of mediation analyses, we found that the path from organizational cronyism to career satisfaction is significant and standardized solution estimates are -.46 in measurement model and -.32 in structural model. Decreasing the standardized solution estimates point out that organizational commitment partially mediates the relationship between organizational cronyism and career satisfaction. On the other hand, the standardized solution value of the path from organizational cronyism to frustration with work is .67 in the measurement model and .51 in the structural model. Taking this significant decrease into account, we could say organizational commitment partially mediates the relationship between organizational cronyism and frustration with work.

The final model with standardized estimates is shown in Figure 3.

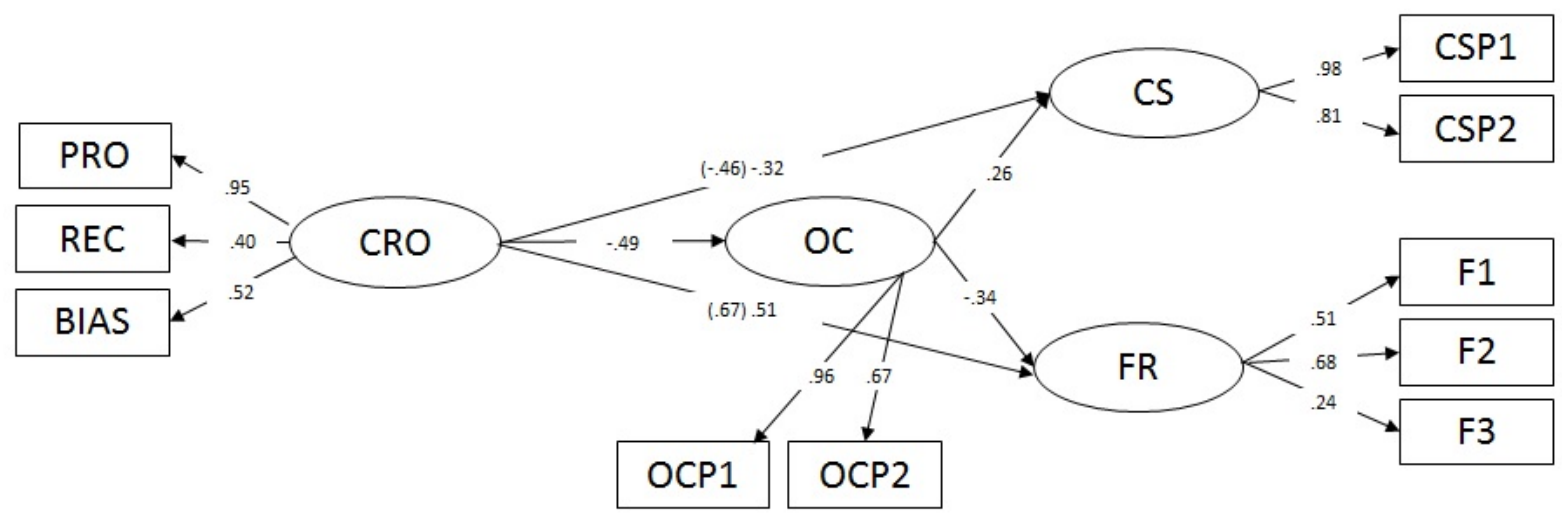

Figure 3. Standardized parameter estimates of the final structural model

$\mathrm{N}=193$, CRO organizational cronyism; OC organizational commitment; CS career satisfaction; FR frustration with organization; PRO cronyism in reward and promotion, REC cronyism in recruitment, BIAS in-group bias are factors of CRO; OCP1-OCP2 are parcels of OC; CSP1-CSP2 parcels of CS; F1-F2-F3 items of FR. All factor loadings and parameter estimates are significant at $\mathrm{p}<.01$. 


\section{Discussion and Conclusion}

There are emerging stream of works on organizational ethics in the literature; however, organizational cronyism has been investigated very sparsely in comparison to other concept evaluated ethics literature (Khatri and Tsang, 2003). In addition, few empirical researches investigating favoritism and cronyism could be found in the field of management literature (Turhan, 2014). Contributing to the concept of cronyism in organization level, the present research was designed in order to investigate negative effects of organizational cronyism on individual and organizational outcome. On the scope of government officials in public organization, we endeavor to explain their career satisfaction and frustration with work. In addition, commitment is taken into consideration to investigate the relationship among the concepts of organizational cronyism, career satisfaction and frustration with work.

To control the consistency of the measures, we attained acceptable reliability and internal consistency in organizational cronyism, organizational commitment, career satisfaction and frustration with work scales. Furthermore, the results of confirmatory factor analysis conducted on organizational cronyism scale confirmed the previous research (Asunakutlu and Avci, 2010) with adequate internal consistency.

Relationships among the variables attained from measurement model pointed out that organizational cronyism is negatively related to organizational commitment and career satisfaction. This result was confirmed by Ferrinho et al.'s (2004) and Zinnen et al.'s (2012) researches, because they had found working condition improvement and effective career improvement program design without favoritism caused organizational commitment and satisfaction with organization. Furthermore, Bute (2011) had found significant negative relationship between nepotism and organizational commitment. In the present research, it was found that organizational commitment and career satisfaction were positively in relation. The result was also supported implicitly by Mathieu and Zajac (1990) and Mowday et al. (1982), because they asserted high committed employees experienced low level career stagnation and had high level career prospects. In addition, the result of this study exhibited that organizational cronyism and frustration with work were positively in relation. The outcome was verified by Chang et al.'s (2014) research implication.

Structural model results indicated that organizational cronyism was negatively associated with career satisfaction. Moreover, organizational cronyism and organizational commitment were in negative relation, while organizational commitment and career satisfaction were in positive relation. According to the nested model strategy (Anderson and Gerbing, 1988) and Baron and Kenny's (1986) mediation methodology, we found that there was significant relationship between organizational cronyism and career satisfaction directly and by means of organizational commitment indirectly. So it could be claimed that organizational commitment partially mediates the relationship between organizational cronyism and career satisfaction. Structural model testing also shows that organizational cronyism is negatively in relation with organizational commitment and positively in relation with organizational frustration. Furthermore, there is positive relationship between organizational cronyism and frustration with organization. As indicated in the structural model, organizational commitment partially 
mediates the relationship between organizational cronyism and frustration with organization (Anderson and Gerbing, 1988; Baron and Kenny, 1986).

It is evidenced by the implication of the structural model testing that if employees do not perceive organizational cronyism and they are highly committed to their organization, their career satisfaction could increase and frustration with work could decrease. In addition, organizational commitment is a key construct of this research since it could reduce the negative effect of organizational cronyism on career satisfaction. The importance of organizational commitment could be evaluated for future research, because it also reduces organizational frustration of individuals which stems from perceived organizational cronyism. In addition to government officials in public organizations, organizational cronyism should be investigated in different sectors and at different level of analysis in further studies. Furthermore, many other concepts can be explained by the concept of organizational cronyism.

\section{References}

Aasland, M., Skogstad, A., Notelaers, G., Nielsen, M., \& Einarsen, S. (2010). The prevalence of destructive leadership. British Journal of Management, 21(2), 438-452.

Abdalla, H. F., Maghrabi, A. S., \& Raggad, B. G. (1998). Assessing the perceptions of human resource managers toward nepotism: A cross-cultural study. International Journal of Manpower, 19(8), 554-570. http://dx.doi.org/10.1108/01437729810242235

Anderson J. C., \& Gerbing D. W. (1988). Structural equation modeling in practice: A review and recommended two-step approach. Psychological Bulletin, 103(3), 411-423. http://dx.doi.org/10.1037/0033-2909.103.3.411

Arasli, H., \& Tumer, M. (2008). Nepotism, Favoritism and Cronyism: A study of their effects on job stress and job satisfaction in the banking industry of north Cyprus. Social Behavior and Personality: An International Journal, 36(9), 1237-1250. http://dx.doi.org/10.2224/sbp.2008.36.9.1237

Aryee, S., Chay, Y. W., \& Tan, H. H. (1994). An examination of the antecedents of subjective career success among a managerial sample in Singapore. Human Relations, 47(5), 487-509. http://dx.doi.org/10.1177/001872679404700502

Asunakutlu, T., \& Avci, U. (2010). An investigation of the relationship between nepotism and job satisfaction in family business. Suleyman Demirel University The Journal of Economics and Administrative Sciences, 15(2), 93-109.

Baron, R. M., \& Kenny, D. A. (1986). The moderator-mediator variable distinction in social psychological research: Conceptual, strategic, and statistical considerations. Journal of $\begin{array}{llll}\text { Personality and Social Pschology, 51(6), } & \text { 1173-1182. }\end{array}$ http://dx.doi.org/10.1037/0022-3514.51.6.1173

Bellow, A. (2003). In Praise of Nepotism: A Natural History. Newyork: Doubleday Publishing. 
Blase, J., \& Blase, J. (2003). The phenomenology of principal mistreatment: Teachers' perspectives. Journal of Educational Administration, 41(4), 367-422. http://dx.doi.org/10.1108/09578230310481630

Blase, J., \& Blase, J. (2006). Teachers' perspectives on principal mistreatment. Teacher Education Quarterly, 33(4), 123-142.

Brewer, B., Leung, J. Y., \& Scott, I. (2015). Value-Based Integrity Management and Bureaucratic Organizations: Changing the Mix. International Public Management Journal, forthcoming. http://dx.doi.org/10.1080/10967494.2015.1030053

Bute, M. (2011). The effects of nepotism and favoritism on employee behaviors and human research management practices: A research on Turkish public banks. Amme Idaresi Dergisi, 44(1), 135-153.

Chang, Y. P., Wang, H. H., Huang, S., \& Wang, H. I. (2014). Interaction effect of work excitement and work frustration on the professional commitment of nurses in Taiwan. Journal of Nursing Research, 22(1), 51-60. http://dx.doi.org/10.1097/jnr.0000000000000021

Chatman, J. A., \& O'Reilly, C. A. (1990). Building organizational commitment: A multifirm study. Journal of occupational Psychology, 63, 245-261. http://dx.doi.org/10.1111/j.2044-8325.1990.tb00525.x

Chen, Z. X., \& Francesco A. M. (2000). Employee demography, organizational commitment, and turnover intentions in china: Do cultural differences matter? Human Relations, 53(6), 869-887. http://dx.doi.org/10.1177/0018726700536005

Dobson, R., Backman, A., \& Keegon D. (2007). Factors associated with career satisfaction among general practitioners in Canada. Canadian Journal Rural Medicine, 12(4), 217-230.

Ferrinho, P., Van Lerberghe, W., Fronteira, I., Hipólito, F., \& Biscaia, A. (2004). Dual practice in the health sector: Review of the evidence. Human resources for health, 2(1), 14. http://dx.doi.org/10.1186/1478-4491-2-14

Fields, D. L. (2002). Taking the measure of work: A guide to validated scales for organizational research and diagnosis. New Delphi, London: Sage Publication.

Fortunato, V. J., Jex, S. M., \& Heinish, D. A. (1999). An examination of the discriminant validity of the strain-free negative affectivity scale. Journal of Occupational and Organizational Psychology, 72, 503-522. http://dx.doi.org/10.1348/096317999166815

Fox, S., \& Spector, P. E. (1999). A model of work frustration-aggression. Journal of Organizational Behavior, 20(6), 915-931. http://dx.doi.org/10.1002/(SICI)1099-1379(199911)20:6<915::AID-JOB918>3.0.CO;26

Garih, U. (2000). Yonetim Ilkeleri. Istanbul: Hayat Publishing.

Goldberg, M. S. (1982). Discrimination, nepotism, and long-run wage differentials. The 
Quarterly Journal of Economics, 97(2), 307-319. http://dx.doi.org/10.2307/1880760

Greenhaus J. H., Parasuraman S., \& Wormly M, (1990). Effects of race on organizational experiences, job performance evolution and career outcomes. Academy of Management Journal, 33(1), 64-86. http://dx.doi.org/10.2307/256352

Herzberg, F. (1964). The motivation-hygiene concept and problems of manpower. Personal Administration, 27(1), 3-7.

Hochwarter, W. A., \& Thompson, K. W. (2012). Mirror, mirror on my boss's wall: Engaged enactment's moderating role on the relationship between perceived narcissistic supervision and work outcomes. Human Relations, 65(3), 335-366. http://dx.doi.org/10.1177/0018726711430003

Holland, J.L. (1959). A theory of vocational choice. Journal of Counseling Psyhology, 6(1), 35-45. http://dx.doi.org/10.1037/h0040767

Hong, S. (2015). Representative Bureaucracy, Organizational Integrity, and Citizen Coproduction: Does an Increase in Police Ethnic Representativeness Reduce Crime? Journal of Policy Analysis and Management, forthcoming.

Jex, S. M., \& Elacqua, T. C. (1999). Self-esteem as a moderator: A comparison of global and organization-based measures. Journal of Occupational and Organizational Psychology, 72(1), 71-81. http://dx.doi.org/10.1348/096317999166509

Jex, S. M., \& Gudanowski, D. M. (1992). Efficacy beliefs and work stress: An exploratory study. Journal of Organizational Behavior, 13(5), 509-517. http://dx.doi.org/10.1002/job.4030130506

Jex, S. M., Beehr, T. A., \& Roberts, C. K. (1992). The meaning of occupational stress items to survey respondents. Journal of Applied Psychology, 77(5), 623. http://dx.doi.org/10.1037/0021-9010.77.5.623

Keles, H. N., Özkan, T. K., \& Bezirci, M. (2011). A study on the effects of nepotism, favoritism and cronyism on organizational trust in the auditing process in family businesses in Turkey. International Business \& Economics Research Journal (IBER), 10(9), 9-16.

Khatri, N., \& Tsang, E. W. K. (2003). Antecedents and consequences of cronyism in organizations. Journal of Business Ethics, 43(4), 289-303. http://dx.doi.org/10.1023/A:1023081629529

Lillis, M., Krystofiak, F., \& Newman, J. (2007). Doing more harm than good: Unraveling the mystery of frustration effects. Journal of the American Academy of Business, 11(1), $154-160$.

Lincoln, J. R., \& Kalleberg, A. L. (1990). Culture, control and commitment: A study of work organization and work attitudes in the United States and Japan, Cambridge: Cambridge Press.

Marsden, P. V., Kalleberg, A. L., \& Cook, C. R. (1993). Gender differences in organizational 
commitment influences of work positions and family roles. Work and Occupations, 20(3), 368-390. http://dx.doi.org/10.1177/0730888493020003005

Martins, P. S. (2010). Cronyism, Bonn: IZA, Discussion Paper no: 5349.

Mathieu, J. E., \& Zajac, D. M. (1990). A review and meta-analysis of the antecedents, correlates, and consequences of organizational commitment. Psychological Bulletin, 108(2), 171-194. http://dx.doi.org/10.1037/0033-2909.108.2.171

Mc Ginley, M. D. (2009). Effects of career and marriage on newlywed individuals' marital and career satisfaction (Unpublished doctoral dissertation). University of Florida, USA.

Meric, E., \& Erdem, M. (2013). İlköğretim okullarında görev yapan öğretmenlerin algılarına göre okul yönetiminde kayırmacılık. Kuram ve Uygulamada Eğitim Yönetimi, 19(3), 467-498.

Meyer, J. P., \& Allen, J. N. (1997). Commitment in the workplace. Thousand Oaks, CA: Sage.

Mowday, R. T., Porter, L. W., \& Steers, R. M. (1982). Employee-Organization Linkages: The Psychology of Commitment, Absenteeism and Turnover. New York: Academic Press.

Oh, J. R. (2014). Organizational justice as the antecedent of career satisfaction. The Journal of the Korea Contents Association, 14(11), 915-929. http://dx.doi.org/10.5392/JKCA.2014.14.11.915

Ozsemerci, K. (2003). Corruption in Turkish public administration: Causes, losses and suggestion. Ankara: Sayistay Publishing.

Park, S. (2011). The influence of organizational justice and career plateau perceptions on organizational effectiveness. Korean Society and Public Administration, 21(4), 1-23.

Pearce, J. L., Branyiczki, I., \& Bigley, G. A. (2000). Insufficient bureaucracy: Trust and commitment in particularistic organizations. Organization Science, 11(2), 148-162. http://dx.doi.org/10.1287/orsc.11.2.148.12508

Peters, L. H., O'Connor, E. J., \& Rudolf, C. J. (1980). The behavioral and affective consequences of performance-relevant situational variables. Organizational Behavior and Human Performance, 25(1), 79-96. http://dx.doi.org/10.1016/0030-5073(80)90026-4

Rauh, J. (2015). Predicting political influence on state ethics commissions: Of course we are ethical—nudge nudge, wink wink. Public Administration Review, 75(1), 98-110. http://dx.doi.org/10.1111/puar.12290

Roe, A. (1956). The psychology of occupations. Hoboken, NJ, US: John Wiley \& Sons Inc. http://dx.doi.org/10.1037/13192-000

Rosen C., Harris K., \& Kacmar K (2009). The emotional implications of organizational politics: A process model. Human Relations, 62(1), 27-57. http://dx.doi.org/10.1177/0018726708099836

Rosenzweig, S. (1944). An outline of frustration theory. In J. Hunt (Eds.) Personality and the Behavior Disorders. Oxford: Ronald Press, 379-388. 
Salvato, C., Minichilli, A., \& Piccarreta, R. (2012). Faster route to the CEO suite: Nepotism or managerial proficiency? Family Business Review, 25(2), 206-224. http://dx.doi.org/10.1177/0894486511427559

Schein, E. H. (1975). How career anchors hold executives to their career paths. Personnel, 52(33), 11-24.

Seibert, S. E., Crant, J. M., \& Kraimer, M. L. (1999). Proactive personality and career success. $\begin{array}{llll}\text { Journal of Applied } & \text { Psychology, }\end{array}$ http://dx.doi.org/10.1037/0021-9010.84.3.416

Simsek O. F., \& Kuzucu Y. (2012). The gap that makes us desperate: Paths from language to mental health, International Journal of Psychology, 47(6), 467-477. http://dx.doi.org/10.1080/00207594.2011.645479

Spector, P. E. (1978). Organizational frustration: A model and review of the literature. $\begin{array}{lll}\text { Personnel Psychology, } & \text { 815-829. }\end{array}$ http://dx.doi.org/10.1111/j.1744-6570.1978.tb02125.x

Spector, P. E., \& O'Connell, B. J. (1994). The contribution of personality traits, negative affectivity, locus of control and Type A to the subsequent reports of job stressors and job strains. Journal of Occupational and Organizational Psychology, 67(1), 1-12. http://dx.doi.org/10.1111/j.2044-8325.1994.tb00545.x

Steers, R. M. (1977). Antecedents and outcomes of organizational commitment. Administrative Science Quarterly, 22(1), 46-56. http://dx.doi.org/10.2307/2391745

Storms, P. L., \& Spector, P. E. (1987). Relationships of organizational frustration with reported behavioural reactions: The moderating effect of locus of control. Journal of $\begin{array}{llll}\text { Occupational Psychology, } & \text { 227-234. }\end{array}$ http://dx.doi.org/10.1111/j.2044-8325.1987.tb00255.x

Super, E. D. (1980). A life-span, life-space approach to career development. Journal of Vocational Behavior, 16(3), 282-298. http://dx.doi.org/10.1016/0001-8791(80)90056-1

Tremblay, M., Dahan, J., \& Gianecchini, M. (2014). The mediating influence of career success in relationship between career mobility criteria, career anchors and satisfaction with organization. Personnel Review, 43(6), 818-844. http://dx.doi.org/10.1108/PR-08-2012-0138

Turhan, M. (2014). Organizational cronyism: A scale development and validation from the perspective of teachers. Journal of Business Ethics, 123(2), 295-308. http://dx.doi.org/10.1007/s10551-013-1839-3

Turner, J. C., Brown, R. J., \& Tajfel, H. (1979). Social comparison and group interest in ingroup favouritism. European Journal of Social Psychology, 9(2), 187-204. http://dx.doi.org/10.1002/ejsp.2420090207

Zinnen, V., Paul, E., Mwisongo, A., Nyato, D., \& Robert, A. (2012). Motivation of human resources for health: A case study at rural district level in Tanzania. The International Journal of Health Planning and Management, 27(4), 327-347. 
http://dx.doi.org/10.1002/hpm.2117

\section{Appendix}

Appendix 1. Confirmatory Factor Analysis for Organizational Cronyism Scale

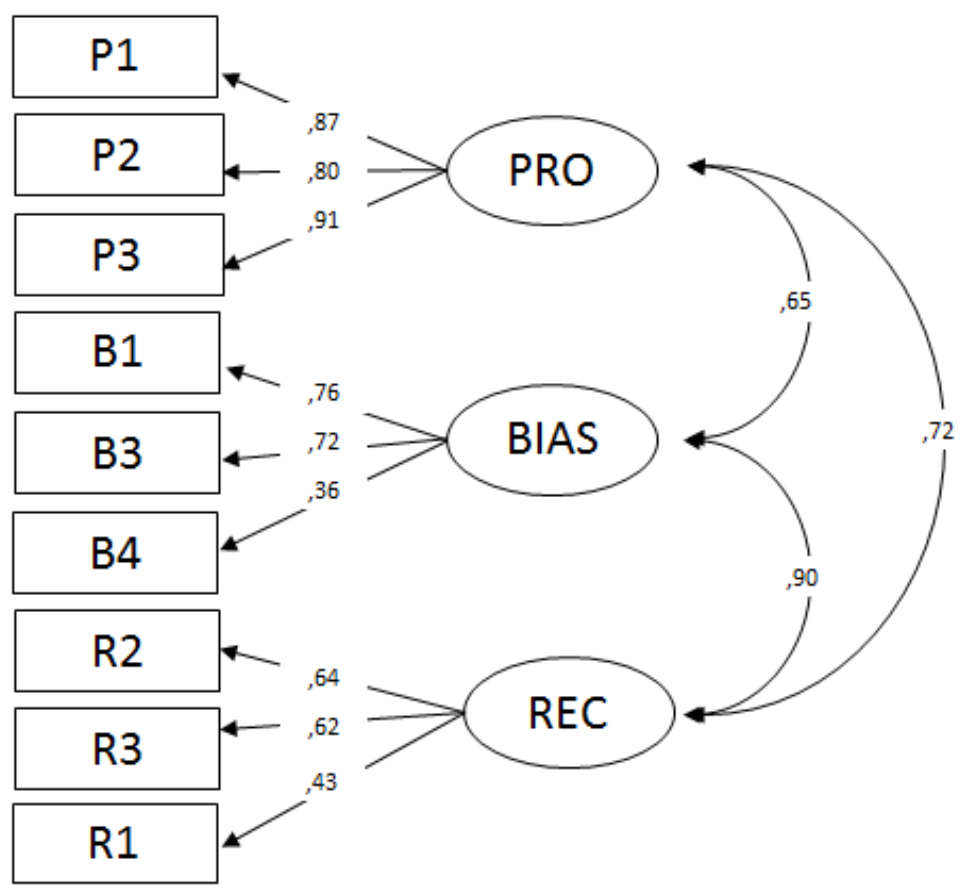

Figure 4. Confirmatory Factor Analysis Loadings for Organizational Cronyism Scale

$\mathrm{N}=193$; PRO cronyism in reward and promotion; BIAS in-group bias; REC cronyism in recruitment. P1-P2-P3 items of cronyism in reward and promotion (PRO); B1-B3-B4 items of in-group bias (BIAS); R1-R2-R3 items of cronyism in recruitment (REC). All parameters are significant at the $\mathrm{p}<.01$.

\section{Copyright Disclaimer}

Copyright for this article is retained by the author(s), with first publication rights granted to the journal.

This is an open-access article distributed under the terms and conditions of the Creative Commons Attribution license (http://creativecommons.org/licenses/by/3.0/). 